\title{
Saudi Arabian Students' Knowledge of the Provisions Governing Interactions between Muslims and Non-Muslims
}

\author{
Tareq S. Albhlal ${ }^{1}$ \\ ${ }^{1}$ Department of Islamic Contemporary Studies, Faculty of Science and Humanities at Rumah, Majmaah University, \\ Riyadh, Saudi Arabia \\ Correspondence: Tareq S. Albhlal, Department of Islamic Contemporary Studies, Faculty of Science and \\ Humanities at Rumah, Majmaah University, 11952, Riyadh, Saudi Arabia. Tel: 966-5-0521-7237. E-mail: \\ talbhlal@mu.edu.sa
}

Received: July 14, 2020

doi:10.5539/jpl.v13n4p59
Accepted: September 8, 2020

Online Published: October 13, 2020

URL: https://doi.org/10.5539/jpl.v13n4p59

\begin{abstract}
Introduction: This study investigates the level of university students' knowledge about Islamic provisions concerning relationships between Muslims and non-Muslims. The context for this study is that of the Saudi Arabian government's drive to combat the extremism of young male Saudis through inculcating the true message of Islam. To achieve this objective, specialist Intellectual Awareness Units (IAUs) have been set up in all Saudi Arabian universities. The rationale for the existence of these units is that such students, zealous in their faith, are more vulnerable to recruitment by extremists and terrorist organizations if they have only a superficial and distorted understanding of the humane and religiously-ordained provisions in the Quran regarding relations with nonMuslims. However, this study does not examine the workings of the Intellectual Awareness Units but rather the understanding of their clients.
\end{abstract}

Methodology: A random sample of 100 male students attending Majmaah University, Saudi Arabia, during the 2019-20 academic year, was asked to participate in a descriptive survey. A questionnaire was devised to collect information about student understanding of appropriate relationships between Muslims and non-Muslims, as specified in the Holy Quran. Six key themes were addressed in the questionnaire: general principles concerning the relationship between Muslims and others; provisions concerning imitation (of non-Muslim religious practices), contact, alliances and enmity; provisions concerning temples and churches; provisions concerning marriage and food; provisions concerning feasts and religious occasions and general provisions concerning alliances and wars.

Results: The results of the study revealed that students' knowledge about the provisions for dealing with nonMuslims ranged from weak to medium. That is to say, knowledge about the appropriate way for Muslims to engage with non-Muslims was far from universal. Knowledge on marriage and food provisions scored most highly with an average of $60.3 \%$, of students answering questions on this topic correctly whilst knowledge on provisions pertaining to Temples and Churches ranked lowest with a rate of $36.5 \%$. The overall average for all issues was $48.9 \%$.

Conclusion: If it is considered that extremism is based upon a superficial and distorted understanding of the Quran and that the level of knowledge displayed by the study sample is typical of young men in Saudi Arabia then the IAUs still have much work to do. The results of this research will be invaluable to the IAUs because it will enable them to supply more nuanced information and activities to their target audience.

Keywords: interactions with non-Muslims, Islamic provisions, Temples, churches, religious feasts, intellectual awareness units (IAUs), intellectual security

\section{Introduction}

This study investigates the level of university students' knowledge about Quranic provisions concerning relationships between Muslims and non-Muslims. The context for the study is that of the Saudi Arabian government's long-held desire to combat the extremism of young male Saudis through inculcating the true message of Islam.

The fight against terrorism towards non-Muslims has received attention from researchers from all over the world. Many countries have allocated huge sums of money to fight this terrorism. The response of the Kingdom of Saudi 
Arabia (KSA) to this growing problem was unique and pioneering: the Kingdom undertook the rehabilitation and treatment of terrorists by making such persons undertake a series of programs during their time in prison.

However, more recently, attention has been paid to the issue of prevention and how to stop persons falling into criminal ways in the first place. Many authorities have contributed to this project, especially after the appalling succession of terrorist crimes following the emergence of armed Islamic movements such as Al Qaeda, Boko Haram, and ISIS. The wide spread use of media materials by such groups targeted towards young people has led to a series of incentives from the Ministry of Education leading to the establishment of Intellectual Awareness Units (IAUs) in all universities and education departments in the Kingdom. These Units (IAUs) have been established in all Saudi universities since $1435 \mathrm{~h}$ (the year 2014).

The men appointed to run these units are specialists in Islamic law, education and psychology, and are selected for their peaceful and moderate approach. These units themselves collaborate with justice, advocacy, educational and security institutions in order to achieve their goal of constructing a moderate society that advocates tolerance, and renounces violence. Their aim is to develop and implement rigorous ways of protecting Saudi Arabian society from future attacks from corrupt and thus dangerous ideologies.

According to the university website, the Intellectual Awareness Unit at the Majmaah University (the location for this study) is designed to,

mentally and psychologically guard its students in particular and ...Saudi youth in general against extremism through spreading awareness of the balanced Islamic ideology founded on the Holy Quran and Sunnah of the Prophet Muhammad (PBUH) as well as the approach of the pious followers.

The Unit seeks to "reinforce[e] ... Islamic values and the well-balanced behavior of Saudi youth in order to ensure an academic safe environment suitable for students and supportive of study and society's stability at large." Thus the unit is committed to "maintaining national security in addition to preventing young people from ideas and values alien to [the Kingdom]." The web page also explicitly states that its brief is to "strengthen intellectual immunity among students against hyperbole and terrorism" and to this end the Unit holds activities and events such as conferences, workshops and seminars. The mission statements for IAUs at other institutions (for example, that at Shaqra University) are broadly similar.

Given the invaluable contribution of the Intellectual Awareness Units in universities, in spite of the difficulties presented to them, more research is needed in order to assist them in pinpointing more accurately where their guidance is needed. This study seeks to contribute to the work of the IAUs.

Thus, the rationale for the existence of these units is that young male Muslims, zealous in their faith, are more vulnerable to recruitment by terrorist organizations if they have only a superficial and distorted understanding of the humane and religiously-ordained provisions in the Quran regarding relations with non-Muslims. However, this study does not examine the workings of the Intellectual Awareness Units but rather the understanding of their clients.

The lack of adequate and accurate details of what students need to know to avoid brain-washing by terrorists is one of the biggest headaches for the intellectual awareness units' staff. Scientific research on the issues students need to understand is needed in order to help IAUs to prepare proper programs, courses, activities and various other initiatives aimed at protecting communities where there is a large population of vulnerable young men from terrorists' deviant ideas.

Ignorance of how to deal with non-Muslims is potentially the most serious gap in knowledge that can be exploited by extremist movements in order to attract young people to their causes. This study examines university students' knowledge of how to deal with non-Muslims by testing their knowledge of six key aspects of that knowledge: general principles concerning the relationship between Muslims and others; provisions concerning imitation (of non-Muslim religious practices), contact, alliances and enmity; provisions concerning temples and churches; provisions concerning marriage and food; provisions concerning feasts and religious occasions and general provisions concerning alliances and wars.

The main research question to be answered by this study is simply this: to what extent do university students know about Islamic provisions regarding how to interact with non-Muslims?

This research comes at a time when many countries in the Middle East have started changing their rhetoric from expressing a morbid fear of foreign cultures to expressing the desire to interact with, and understand, them. Correspondingly, they are adopting strategies in order to embrace this greater interaction as long-term goal. The Kingdom of Saudi Arabia has adopted a policy of accepting and interacting with foreign cultures and has made provision for this new departure in their business development and tourist industry plans. This trend will involve 
both Muslims and Non-Muslims. Higher education in the Kingdom gives this trend an even higher priority, making considerable efforts to create for students a culture of peaceful coexistence and tolerance in interactions with nonMuslim foreigners.

This ideal of peaceful coexistence with the outsider is nothing new; it is a set of provisions taken directly from the Quran and it entails precisely the concepts that are engaged with in this research. Mohammed Alesaa (of the General Secretariat for the Organization of Islamic Cooperation) calls upon all Saudi Muslims to adopt this culture of peaceful coexistence and tolerance, claiming that educational institutions are the best locations for nurturing this culture. Saudi Universities by their very nature have the proper systems and procedures to develop these concepts through academic programs, teaching subjects, discussion panels and scientific conferences.

This research addresses just one aspect of this huge project of reaching out to other countries with the desire for tolerance and peaceful coexistence. It focuses on the knowledge needed by young Muslims to make the project effective. It means that this field of research is still fertile ground for scientific research.

\section{Literature Survey}

This literature survey is divided into seven sections. The first discusses the concept of intellectual security. Following on from that discussion, there is a section for each of the themes relating to Muslim-non-Muslim relations to be discussed in this study.

\subsection{Intellectual Security}

Intellectual security is defined by Aharbi (2011) as ensuring that common ideologies and the minds of individuals are free from any corrupt ideologies and beliefs that may pose a serious danger to the government and its security. It entails tightening security and achieving social stability by adopting government programmes and plans based on moderating public awareness in order to construct a peaceful society.

Alsudeis (2005) asserts that, under intellectual security, all Muslims in their respective countries feel secure about the components of their identity, as well as their culture and intellectual system, as they are contained with the Holy Quran and Sunnah.

Many researchers, among them Altirefi (2007) and Alaed (2008), observe that intellectual security aims to ensure that all groups are protected from anything that may pose a danger or threat to the security of Islamic ideologies. They argue that youths and students are the largest social groups who are exposed to the negative consequences of corrupt ideologies; thus, they are the groups that most need fruitful education programmes to reinforce intellectual security.

\subsection{General Principles in the Relation of Muslims with Non-Muslims}

Altrefi (2007) argues that, to deal with non-Muslims, there is a need to have a jurisprudence that keeps a balance in dealing with non-Muslims so as to avoid deviating towards aggressiveness without reason. At the same time, he notes, there is a need for Islamic nations to welcome and reach out to non-Muslims for their joint public welfare, and to preserve their dignity and their respective identities.

A Muslim is commanded to deal kindly with a non-Muslim who hurts him or her. God says "Allah does not forbid you from [dealing kindly with] those who do not fight you because of religion and do not expel you from your homes - from being righteous toward them and acting justly toward them. Indeed, Allah loves those who act justly" $(60: 8)$. Thus a Muslim will not be a true Muslim unless he or she is a benign presence in his or her neighbourhood and his or her neighbour feels secure regardless of his or her religious beliefs. As is explicated by Alaed (2008), the rights and duties of non-Muslims include those of protecting their own dignity, having the freedom to choose their religion, and associated issues such as propagating justice and securing justice, securing him/herself from any violence, and expecting good treatment and social collaboration in Islamic countries (Alaed 2008).

A Muslim is permitted to live with others in this world, relying on a number of provisions adopted under Islam. God says, "This day those who disbelieve have despaired of [defeating] your religion; so fear them not, but fear Me. This day I have perfected for you your religion and completed My favor upon you and have approved for you Islam as [a] religion. However, whoever is forced by severe hunger [to do wrong] with no inclination to sin - then, indeed, Allah is Forgiving and Merciful" (Al-Ma'ida [5]: 3).

Altriqi (2007) emphasises the humanity inherent in the Islamic tolerance of non-Muslims and in God's universal mercy. He reminds us that God says, "We have sent you [O Muhammad] only as a blessing for the people of the world" (21:107). This verse has two meanings: that the appointment of the Holy Prophet is indeed a blessing and that the mercy of Allah is given to the whole world.

Regarding justice, Alanbya observes that God says, "... your Lord treats no one with injustice" (18:49). With 
regard to keeping promises, in Surah Isrâ God says, "... keep your promise. Surely, the promise will be questioned [enquired after on Judgment Day]" (17:34). In the chapter on prohibiting corruption on the earth, Al-Isra, God says, "... and seek not (occasions for) mischief in the land: for Allah loves not those who do mischief." (28:77) On not forcing non-Muslims to believe in Islam, God says "...There is no compulsion in religion..." (Albaqara [2]:256). This verse sets out the promise made in Islam to give non-Muslims all of their rights, with the most important being freedom of belief (Almimi 1998, 17).

Acting in a manner that shows a lack of respect towards non-Muslims is completely prohibited in Islam. At the same time, however, Muslims must try to persuade non-Muslims to embrace Islam, and must explain to them that Islam is universal and that it is the last religion of all religions and that it negates all other religions. This not just lawful; it is a duty. However, sometimes, the enthusiasm of young Muslims causes them to misinterpret this injunction to proselytize as they build their self-esteem as Muslims by harming and treating non-Muslims in ways which are not in accordance with the Five Pillars of Wisdom.

In so doing, they do not subscribe to God's will which states that one should "not say crude words to those who call upon other than Allah, lest they use crude words about Allah in revenge without knowledge. As such we have made the actions of each nation seem pleasing. To their Lord they shall return, and He will inform them of that they were doing" Al-An'am [6]:108.

As the more aggressive approach to converting Muslims has penetrated the mass media, it has had a negative impact on educational syllabi and family instructions. Most young Muslims interpret legitimate texts without deep knowledge and make up their own minds about what the Quran means on that unsound basis; consequently, false ideas are absorbed by youths and male and female university students (Alqahtani 2020).

\subsection{Provisions Concerning Imitation (of Unbelievers), Contact, Alliances and Enmity}

Islam is a religion that calls upon Muslims to be moral (in speech and action) in their dealings with all mankind and commands them to use good words while speaking. God says, "Say to My servants that they should (only) say those things that are best: for Satan doth sow dissensions among them: For Satan is to man an avowed enemy" AlIsra [17]:53. The Prophet Mohammed (peace be upon him) commands us to be benevolent in our dealings and communication with others regardless of their religion:

"On the authority of Abu Ya'la Shaddad bin Aws (may Allah be pleased with him) ... the Messenger of Allah (peace and blessings of Allah be upon him) said:

Verily Allah has prescribed ihsan (proficiency, perfection) in all things". [Saheeh Muslim, Hadeeth 17116]

All lawful sources of Islam (Hadeeth and the Holy Quran) clarify and describe how Muslims must live with either Muslims or non-Muslims. These legal sources have left nothing for personal discretion, and Islam enacts laws and provisions governing imitation, contact, alliances and enmity.

Alqahtani (2007) contends that the most common sources of extremism are superficial interpretations of the Islamic texts (provisions in the Quran and Hadeeth) and the negative role played by the mass media. Aljhni $(1420 \mathrm{H}$ [year 2000]) convincingly argues that ideologies and destructive doctrines pose a danger to intellectual security as well as to individuals and society.

With regard to contact between Muslims and non-Muslims, results in this present study showed that, individually, participants gave correct answers to between $12 \%$ and $93 \%$ of questions regarding imitation (of non-believers), contact with non-believers, alliances and enmity whilst the percentage of correct answers overall for this theme was $50.6 \%$. The lack of knowledge indicated by these figures shows that it is very important for colleges to address the problem. It follows that any country with a significant Islamic population should design and deliver education programmes to target this problem.

\subsection{Provisions Concerning Temples and Churches}

All places allocated for worship or for carrying out any kind of religious ritual, are included in Quranic provisions regarding temples and churches. God says, "Did not Allah check one set of people by means of another, there would surely have been pulled down monasteries, churches, synagogues, and mosques, in which the name of Allah is commemorated in abundant measure" Al-Hajj [22:]40. All terrorist doctrines cited to justify attacks on the places of worship of non-Muslims pretend that they are executing legitimate Islamic provisions. This is not, however, the case because Islam commands Muslims to treat non-Muslims kindly and to protect them and their churches and temples. Indeed, a true believer respects the freedom and choice of worship of non-Muslims whilst also undertaking to protect the places where they worship.

Islamic history is rich experiences in this respect. Many historical documents show that the early caliphates' 
instructions to Islamic war commanders included not attacking worshipers and not destroying their temples. Further, the Prophet Mohammed (peace be upon him) and his companions captured many places and cities, and they never destroyed a single temple or church. The strongest testimony of this historical fact is the survival of the churches in Egypt which were founded before Islam came into existence.

Among the concepts that must be taught to young Muslims is respect for non-Muslims because God created all of us and knows that we have different colours and different languages. Muslims must admit that there are differences among all humankind because of the will of God; therefore, we must live together in a peaceful atmosphere, especially under Islamic law, which clearly explains the general frames and mechanisms for communication with non-Muslims.

The Islamic view about praying in a church or temple is that this is permitted for to Muslims to pray in such a place once it is clean. The Prophet Mohammed (peace be upon him) says, "The earth has been made for me (and my followers) a place for praying and something with which to perform Tayammum (to purify oneself for prayer). Therefore, any one (of my followers) can pray (anywhere) and at any time that the Salat (prayer) is due" (Abukharee, 238). Algurtubee says, It is allowed for all Muslims to pray in any temple or church as long as this place is clean (Algurtubee, $1407 \mathrm{~h}$, [1987] 8/88; Aluseimi: 2009, 64).

In his study, Alqhtanee (2020) recommends protecting all university students from intellectual terrorism. He argues that it is necessary to protect university students from intellectual extremism by exposing them to the true Islamic vision. This vision is based on many references in the Quran and Hadeeth requiring preservation from extremism (Alqhtanee 2020, 71).

\subsection{Provisions Concerning Marriage and Food}

Islam allows male Muslims to marry Christian or Jewish females. God says, "(Lawful unto you in marriage) are (not only) chaste women who are believers, but chaste women among the People of the Book, revealed before your time, when ye give them their due dowers, and desire chastity, not lewdness, nor secret intrigues. ", (AlMa'idah [5]:5). This verse clearly shows that it is lawful in Islam, and possible for a male Muslim to marry a female who is Christian or Jewish. (In the matter of food, Islam allows Muslims to eat the food of the People of the Book. The Holy Quran says, "The food of the People of the Book is lawful unto you, and yours is lawful unto them" (AlMa'idah [5]:5).

This research study is based on the assumption that ignorance of legitimate provisions in the Quran has led people to misunderstand them. Ignorance of the weekly Hadeeth is a common failing in young Muslims who have corrupt ideologies.

\subsection{Provisions Concern Feasts and Religious Occasions}

Religious festivals are a part of religious rituals; therefore, Islam does not generally approve of religious festivals or encourage participation in rituals. Therefore, only two are formally permitted: Ramadan and Adhaa (a religious ceremony celebrated at the end of the hajj season). Festivals are not actually prohibited for other occasions, provided that the rituals do not include anything that is against Islamic instruction. God says, "Those who witness no falsehood, and, if they pass by futility, they pass by it with honourable (avoidance)" (Al-Furqan [25]:72). Falsehood in this verse means festival (IbnTeymiya 1998, 1/481).

In practice, there are weekly, monthly, and annual festivals but these are not formally approved by Islam. Moreover, Islamic instructions prohibit Muslims from celebrating non-Islamic festivals. There is no provision in Islam which prohibits non-Muslims from celebrating or practising their rituals in festivals but, in spite of this, non-Muslims have suffered from terrorist attacks such as the one perpetrated by Ismael Ismael Mustafa and the two terrorist attacks that took place in the Marmina church in Halwan, Egypt in 2017 which claimed a number of victims including 8 Christians and a Muslim policeman.

In the view of Professor Suleiman Algusn (2016), the extremists who carried out these deeds falsely used Islamic provisions. One of the causes of extremism is the misuse of analogy in Islam. Extremists preach false doctrines and claim that these doctrines belong to mainstream Islam.

\subsection{Provisions Concerning Alliances and Wars}

Islam is the religion of peace and justice. God says, "Allah forbids you not, with regard to those who fight you not for (your) Faith nor drive you out of your homes, from dealing kindly and justly with them: for Allah loveth those who are just" (Al-Mumtahinah [60]:8). Regarding all humankind, it is not fair to persecute non-Muslims because of their different religions (Abu Zahara 1995, 34). There are also Islamic provisions instructing Muslims how to treat prisoners of war, and these provisions are considered to be international law. 
Both the Quran and Hadeeth set out obligations of loyalty to God and to the Prophet Mohammed as well as the need to reject blasphemy and the doctrines of unbelievers. The Quran says, "[O]bey Allah and the Messenger that you may obtain mercy (Il- Imran [2]:132). In Islam, there are also many, many provisions regarding enmity. For example, Muslims are told with regard to their enemies, "Allah forbids you not, with regard to those who fight you not for (your) Faith nor drive you out of your homes, from dealing kindly and justly with them." (AlMumtahinah [60]:8) Misunderstandings about enmity and loyalty are a factor in extremism. Extremists think that any loyalty to unbelievers is blasphemy and that it is legal to shed the blood of right-minded Muslims who ally themselves with unbelievers. Such extremists also claim that agreements with unbelievers are a kind of blasphemy, and thus they make no discrimination between lawful and unlawful loyalty and enmity.

All the Quranic provisions concerning war and alliances with non-Muslims and any legitimate doctrines concerning loyalty and enmity have been rejected by extremists. It is the responsibility of all those with appropriate knowledge such as those who work in mosques, academic teachers and the staff in Intellectual Awareness Units to fight these aggressive ideologies. Islam does not command Muslims to kill haphazardly. This study contributes to motivating all responsible parties to immunize youth against corrupt ideology.

All the research papers outlined above are theoretical; they rely on research problems and objectives to give them scientific credibility. By comparison, this present research is a quantitative-method field study in which the knowledge of a specific sample of young Muslim men was tested. The aim of the study was to identify the participants' knowledge of the provisions that govern interactions between Muslims and non-Muslims. This study now turns to the methodology used and the results obtained.

\section{Methodology}

The main research question that is addressed in this study is: To what extent do university students know about Islamic provisions regarding how to interact with non-Muslims? In order to answer this question, exploratory and descriptive approaches were used, as defined by Babbie (2002). Babbie observes that, whilst exploratory studies cannot give definitive answers to research questions, they can be indicative and suggest directions for future research.

The researcher collected the required data through a questionnaire which presented to the participants in the study a range of items regarding provisions for dealing with non-Muslims and offered a number of possible responses: Duty / Lawful / Abhorrent / Prohibited / I do not know. The participants in the study had to tick one of these options. In other words, the students in question had to indicate whether they thought that the item was about something required, permitted, frowned upon or forbidden by mainstream Islam. The students were familiar with these categories because they had heard them at school and university and at the mosque and because the terms were standard categories used in Sharia Law. The resultant data was then used to measure the extent of students' knowledge of these provisions. The questionnaire was administered in Arabic as this was the first language of every participant in the study.

The study population was drawn from across all undergraduate academic programs and all levels of study at Majmaah University in kingdom of Saudi Arabia. A random sample of one hundred students participated. All the students were male, in line with advice from the Intellectual Awareness Units that young males with an incomplete or distorted understanding of the provisions in the Quran and the traditions of the prophet Mohammed for interactions with non-Muslims are most vulnerable to extremisms. The hardcopy printed questionnaires were handed to, and collected from the students by a group of university professors who worked with the researcher.

The overarching research question was devised and guided by provision in the Quran regarding treatment of nonMuslims. These provisions were divided into six themes and then broken down into the individual items on the questionnaire that the participants were required to comment on. There were 64 items in all. For example, Theme (1), General Principles contained 13 separate items each requiring a response. The six themes were:

1) General Principles that Govern Relations between Muslims and Others

2) Imitation (of non-Muslims), Contact, Alliance and Enmity

3) Temples and Churches

4) Marriage and Food

5) Religious Feasts and Occasions

6) Issues such as Alliances and Wars

These themes were identified in, and collated from, the studies to be found in the literature review. 
The data was analysed using simple percentage calculations. The 100 questionnaires were reviewed and a mark of 1 was given for each correct answer and zero for each incorrect answer. No participant entered a response of "I don't know" so this could not skew any individual scores or overall percentages. The incorrect answers were discarded and focus was upon the correct answers.

SPSS processes were then run to turn these scores into percentages of correct answers in the following ways:

- Each participant's percentage score was calculated for each theme. For example a student might have responded correctly to $60 \%$ of the items about Temples and Churches (Theme (3)). These individual scores were then used to create a range of correct answers that indicated individual levels of knowledge. Thus, the range of individual scores for Theme (3) was between $8 \%$ and $77 \%$.

- An overall percentage of correct answers was calculated for each theme (that is, it was based on the answers from all 100 participants) to show the overall level of knowledge and to provide an indication of where more teaching might be needed.

- The percentage of correct answers for each theme was broken down by age and academic department. This was so that the researcher could determine whether scores were affected by these obvious independent variables.

\section{Analysis}

Thirteen items were introduced to the student participants to determine their familiarity with the general provisions that govern reciprocity between Muslims and non-Muslims (Theme (1)). Table (1) below shows the correct answers for Theme (1) broken down by academic department as well as the total percentage of correct scores over all for that theme.

Table 1. Percentages of correct answers for General provisions
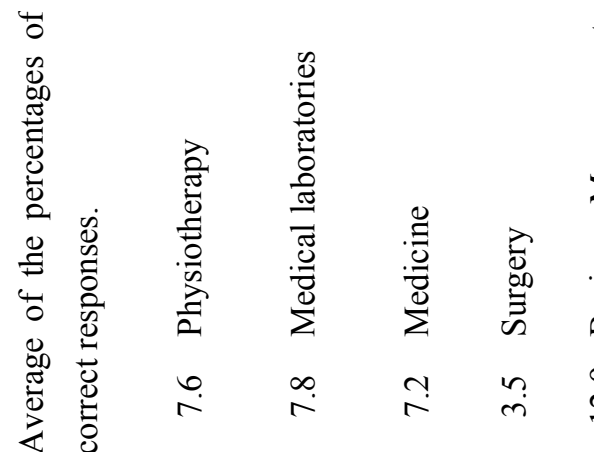

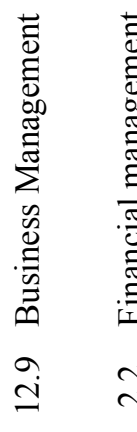

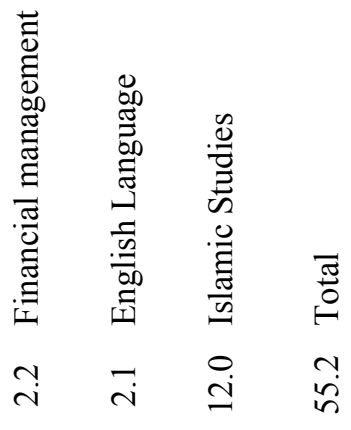

As may be seen, the percentage of correct responses for theme (1) was $55.2 \%$ over all. This percentage shows that the students had medium level of knowledge of the general provisions. Correct responses by individual participants for this theme ranged between $32 \%$ and $84 \%$.

Table Two indicates the extent to which the participants were aware of the general provisions concerning imitation, contact, alliances and enmity (theme (2)).

Table 2. Imitation, contact, alliances and enmity

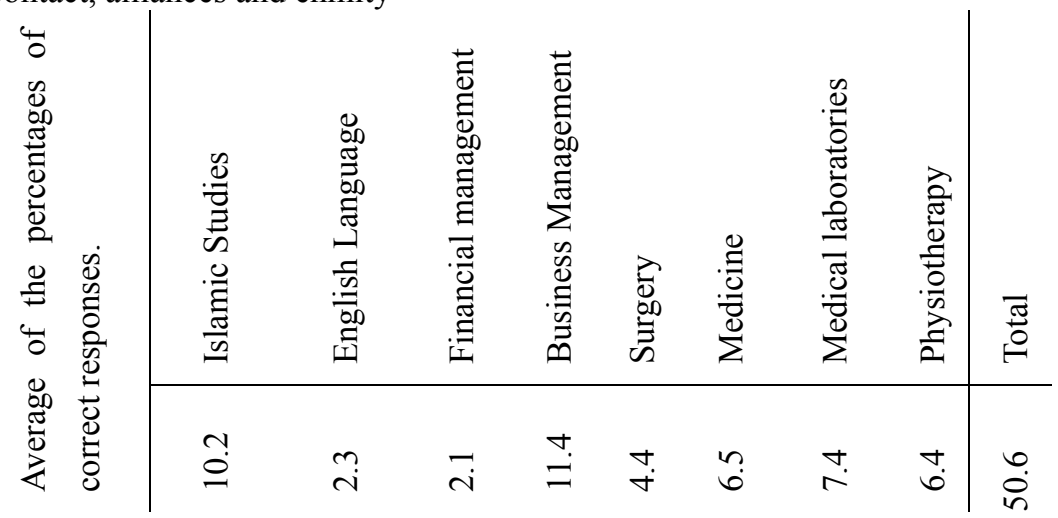


The individual participants' correct responses ranged between $12 \%$ and $93 \%$, and the average percentage of correct responses was $50.6 \%$. This is a medium-level result.

One item regarding a legitimate provision that scored a low number of correct responses was item 12 of Theme (2), which required a response to, "Judging of non-Muslims by citizens when they commit violations". Only twelve out of a hundred students answered correctly. Many Islamic scholars have specifically discussed this issue. Ala'aid $(2008,12)$ observes that non-Muslims who engage in any job in a Muslim country are-protected by the Muslim government and that they have rights and duties.

All the items about relations between Muslim and non-Muslim that received a low number of correct responses must be identified and included in education programmes as a priority. Each of them represents a gap in vital knowledge and hence a vulnerability to terrorists' tendencies. This is why identifying these incorrect answers is a key objective of this study.

Table (3) shows students' awareness of the general provisions concerning temples and churches.

Table 3. Temples and churches

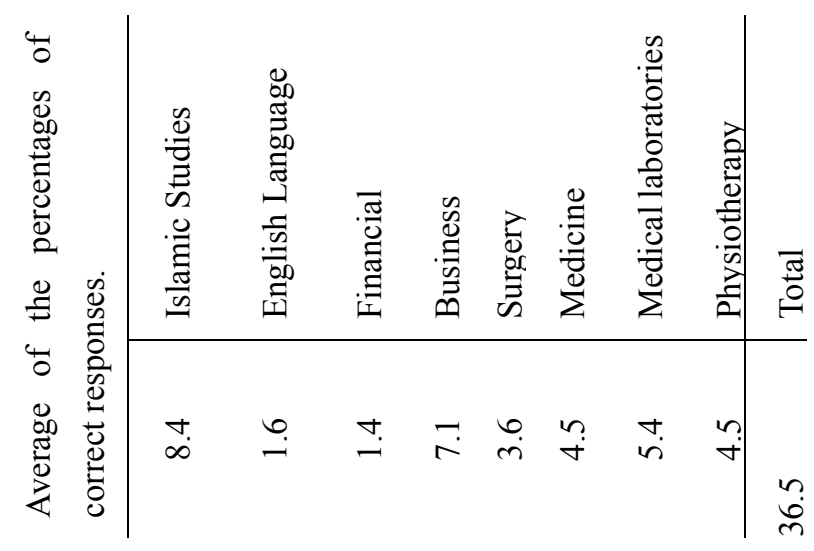

Correct responses over all to the general provisions concerned with temples and churches, Theme (3), stood at a low $36.5 \%$, with the scores for individual participants ranging between $8 \%$ and $77 \%$. This result indicates the extreme weakness of university students' knowledge about general provisions concerning temples and churches. Thus, on spite of the intelligibility of the Quranic provisions with regard to Muslims praying in a Church, only $8 \%$ of responses for this item were correct. This is, therefore, another priority area for action. These results clearly show that university students need to be educated in Islamic provisions regarding such matters and given appropriate evidence to render them invulnerable to blind enthusiasm and negative emotions.

Table (4) shows the participants' knowledge regarding the provisions that govern Muslim marriage with People of the Book (mainly Jews and Christians) and food (Theme (4)).

Table 4. Provisions regarding marriage and food

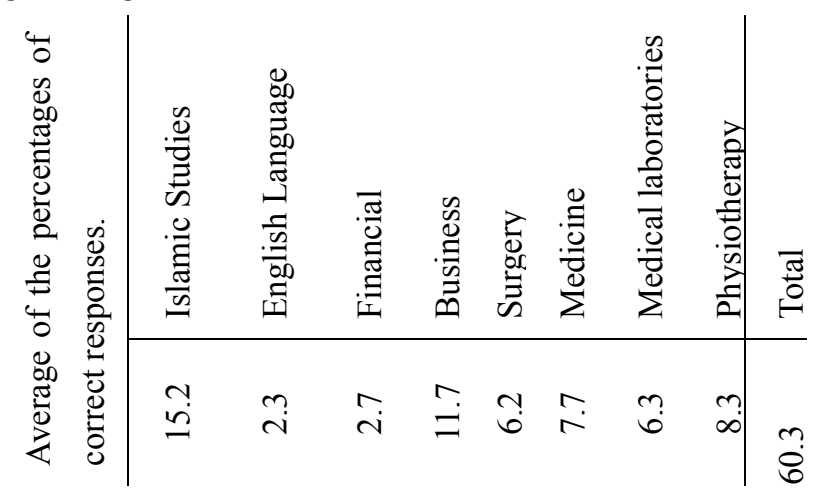

Table Four documents correct responses to all the items in Theme (4). The individual rates of correct results were 
between $38 \%$ and $78 \%$. The average was $60 \%$ - a medium level of awareness. It follows, that it is important to raise such Islamic and juristic matters with university students because it reflects the goodness of Islam to nonMuslims. God allows a male Muslim to marry a female from the People of the Book and to eat their food. This is a juristic problem, but it has very important educational and societal implications for students.

Table (5) shows the extent to which university students are aware of the general provisions for non-Muslims relating to their feasts and religious occasions.

Table 5. Non-Muslim feasts and religious occasions

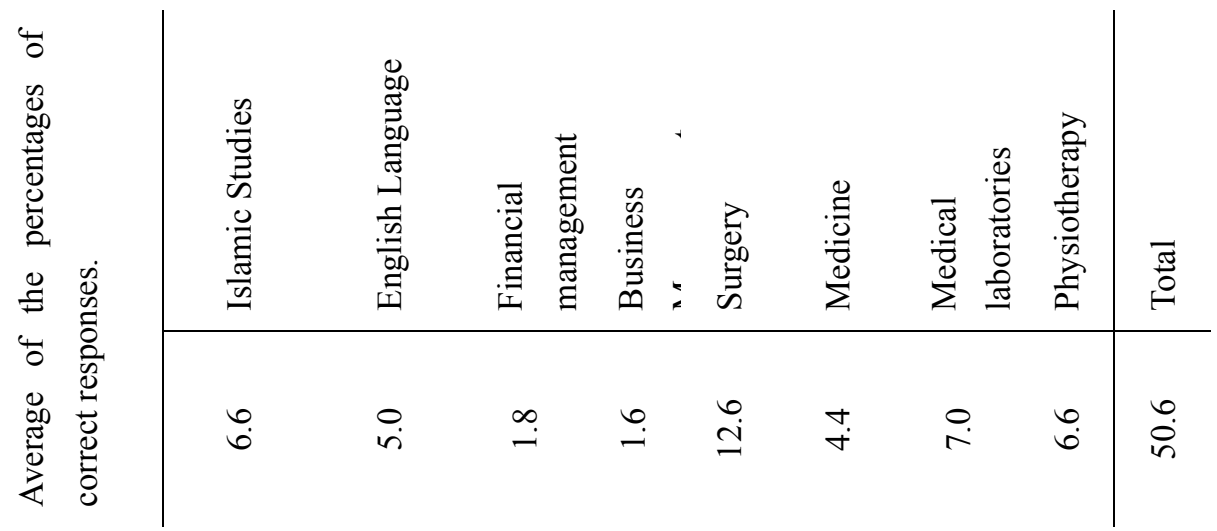

As Table (5) illustrates, the range of correct responses by individual participants was between $45 \%$ and $66 \%$, and the average of all percentages was 51. This was, once more, a medium level response.

Table (6) shows the extent to which university students had accurate knowledge of the general provisions regarding alliances and wars.

Table 6. Alliances and wars

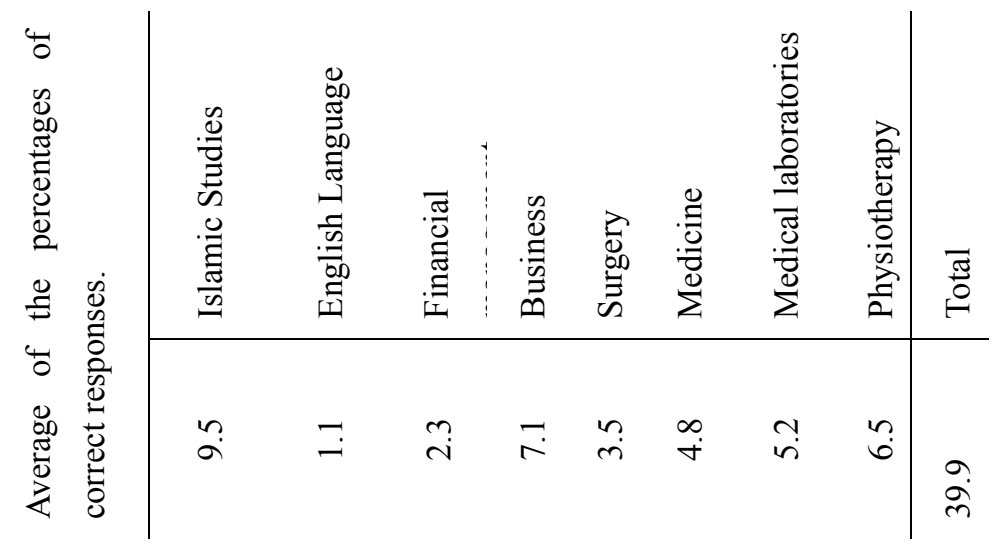

Table (6) sets out the percentage of correct responses to items on the theme of alliances and wars overall. The scores achieved for this theme by individual participants ranged between $12 \%$ and $56 \%$, and the average of the combined scores was $39.9 \%$. This is a weak medium percentage. This result indicates that university students have weak knowledge of the provisions that govern alliances and wars between Muslims and non-Muslims. The low percentage of correct answers makes a worrying parallel with the way in which Muslim militant extremist groups have rejected the explicitly Islamic provisions regarding alliances and wars.

Table Seven gives an overall picture of the extent to which student participants are aware of the Quranic provisions that govern the treatment of non-Muslims, according to the six themes identified for investigation. 
Table 7. Comparison of $\%$ correct answers for each theme

\begin{tabular}{llll}
\hline Theme & Percentage of correct responses & Rank & The level of knowledge \\
\hline The general principles in the relation of Muslims with non-Muslims & 55.2 & 2 & Medium \\
Imitation, contact, alliances and enmity & 50.6 & 4 & Medium \\
Temples and churches & 36.5 & 6 & Weak \\
Food and marriage & 60.3 & 1 & Medium \\
Religious festivals & 51.6 & 3 & Medium \\
Alliances and wars & 39.9 & 5 & Weak \\
Average of the percentages of correct responses. & 49.0 & 2 & Medium \\
\hline
\end{tabular}

Table (7) indicates that students have between a low and medium level of knowledge for all the different themes in this study. This is disturbing because, whilst these average scores are low in themselves, they mask the scores that are lower still. Some participants had individual scores as low as $8 \%$. (Some individual scores were considerably higher than the averages but these young men are not the cause for concern.)

Table (7) illustrates the answer to the research question, and it is possible to conclude that, over all, there is a low medium level of knowledge of the provisions that govern the dealings between Muslims and non-Muslims among university students. The average percentage of correct responses of the axes is $49 \%$.

Table (8) notes the differences in university students' knowledge of the provisions concerning the dealings between Muslims and non-Muslims based on the college parameter.

Table (8) illustrates the differences in university students' knowledge of the provisions concerning dealings between Muslims and non-Muslims based on the parameter of age. (The age range was from 19 to 23.)

Table 8 . Correct responses calculated by age

\begin{tabular}{cccccc}
\hline & Total Scores & Degrees of Freedom & Mean for scores & F & Statistical Function \\
\hline Between groups & 376.829 & 2 & 188.415 & 2.096 & .129 \\
Within groups & 8720.561 & 97 & 89.903 & & \\
The total & 9097.390 & 99 & & & \\
\hline
\end{tabular}

Table (8) shows that, based on the parameter of age, there was no difference in the statistical function related to university students' knowledge of the provisions concerning interactions with non-Muslims.

Table (9) presents differences in the participants' knowledge about provisions concerning Muslims/non-Muslims interactions based on specialization parameters.

Table 9. Variation between scores based on subject specialization

\begin{tabular}{cccccc}
\hline & The total of the scores & Degrees of freedom & The intermediate of the scores & F & The statistical function \\
\hline Between groups & 1343.349 & 7 & 191.907 & 2.277 & .035 \\
Within groups & 7754.041 & 92 & 84.283 & & \\
The total & 9097.390 & 99 & & & \\
\hline
\end{tabular}

The numeric statistical function in Table (9) indicates that there is no significant difference in the participants' knowledge of the provisions concerning interactions with non-Muslims based on the parameter of subject specialization.

Table (10) shows the Functional differences in university students' awareness of the provisions that govern interactions between Muslims and non-Muslims broken down by individual specialization. 
Table 10. Breakdown of functional differences by specialization

\begin{tabular}{|c|c|c|c|c|}
\hline Specialization (I) & Specialization $(J)$ & The difference between intermediates & DeviationStat & tistical functions \\
\hline \multirow{7}{*}{ Physiotherapy } & Medical Laboratories & 4.15476 & 3.61162 & .253 \\
\hline & Medicine & 3.89103 & 3.67517 & .292 \\
\hline & Surgery & 1.58333 & 4.19034 & .706 \\
\hline & Business Management & $7.46333^{*}$ & 3.22411 & .023 \\
\hline & Financial management & 1.83333 & 5.30041 & .730 \\
\hline & English language & $9.78333^{*}$ & 4.88674 & .048 \\
\hline & Islamic Studies & $-1.94298-$ & 3.38519 & .567 \\
\hline \multirow{7}{*}{ Business Management } & Physiotherapy & $-7.46333-^{*}$ & 3.22411 & .023 \\
\hline & Medical Laboratories & $-3.30857-$ & 3.06456 & .283 \\
\hline & Medicine & $-3.57231-$ & 3.13921 & .258 \\
\hline & Surgery & $-5.88000-$ & 3.72917 & .118 \\
\hline & Financial management & $-5.63000-$ & 4.94389 & .258 \\
\hline & English Language. & 2.32000 & 4.49755 & .607 \\
\hline & Islamic Studies & $-9.40632-^{*}$ & 2.79415 & .001 \\
\hline \multirow{7}{*}{ Islamic Studies } & Physiotherapy & 1.94298 & 3.38519 & .567 \\
\hline & Medical Laboratories & 6.09774 & 3.23360 & .062 \\
\hline & Medicine & 5.83401 & 3.30443 & .081 \\
\hline & Surgery & 3.52632 & 3.86928 & .364 \\
\hline & Business Management & $9.40632^{*}$ & 2.79415 & .001 \\
\hline & Financial Management & 3.77632 & 5.05042 & .457 \\
\hline & English Language & $11.72632^{*}$ & 4.61439 & $11.72632^{*}$ \\
\hline
\end{tabular}

Table (10) shows the differences that existed in awareness by the participants' course of study. Islamic Studies students had the highest scores over all and the lowest-scoring specialization was English.

The results taken from the questionnaire show that the participants possessed approximately half of the knowledge that all Saudi Arabian Islamic institutions - from the Crown to the Intellectual Awareness Units - would wish them to have.

\section{Conclusion}

Finally, this paper offers some conclusions in answer to the main research question, "To what extent do university students know about Islamic provisions regarding how to interact with non-Muslims?" and to offer some suggestions for further research.

The data from the questionnaire produced results that gave the main answer to the research question. That answer was that, over all, the participants in this study did not understand the Quranic and Hadeeth-based (and thus legal) injunctions relating to relationships between Muslims and non-Muslims to a great extent. Understanding stood at an overall low medium with the highest percentage of correct answers for any one of the six themes explored standing at $60.3 \%$. (The theme of Marriage and Food obtained this average score.) However, it must be taken into account that the overall percentages for each theme hide a massive variation in individual participants' knowledge. The percentage of correct answers for two of the other themes falls well below 50\%. This will not be encouraging news for anyone who believes that true and in-depth knowledge of Islam is a shield for the vulnerable against the persuasive lies of terrorist organizations. The variables of student participants' age, and specialization do not suggest any recognizable differences with regards to statistical functions.

The findings from this study may act as a guide and reference for students, supervisors, Intellectual Awareness Units, and supervisors of rehabilitation and treatment programs. This study may also ultimately provide an advanced stream of knowledge to governmental security bodies and guide them in their strengthening of the 
intellectual security of university students.

The first recommendation based on this study is, therefore, that new programs to teach students the Quranic and Hadeeth-based provisions regarding non-Muslims should be founded in Saudi Arabia. The second is that the mass media should be used to counter the already-existent mass-media presence of extremists and terrorists, whose distortion of what the Quran and Hadeeth really say about non-Muslims targets the zealous young man and ruins lives.

Some of the scores for the participant sample at Majmaah University were not good. However, it is possible that they could have been lower if the same research had been conducted at a university outside of Saudi Arabia. The sheer numbers and locations of potentially vulnerable students is a strong motivation for giving this subject more consideration by other researchers in the field.

Of course, there is plenty of room for further research inside Saudi Arabia itself. This present study involved 100 students at a single university. Another student-based study of this kind but covering multiple sites would give more depth to the findings and make it possible to investigate a greater range of variables. However, there are numerous other useful areas of investigation for this topic. For example, further research could identify why students are less well informed than expected, given that KSA is, in both legal and religious terms, an Islamic state and the IAUs are working effectively. Such studies might include research that took into account the perspectives of the IAUs and those of the students for which they were created.

\section{Acknowledgement}

"The author is very thankful to all the associated personnel in any reference that contributed to/for the purpose of this research. The author would also like to thank the following:

Firstly: The Intellectual Awareness Unit at Majmaah University for supporting this study.

Secondly: The University Deanship of Scientific Research at Majmaah University for funding this work under Project Number No R-1441-154.

Thirdly: Students who participated in the random sample of the study.

Finally: The editing board and reviewers for their valuable responses and fast reply"

\section{References}

Abd, A. A. (1984). The scientific Methodology, Concept, Tools and Measurement. Amman. Majdwly House press. Abdallh, A. (2007). Treatment with non-Muslims. Dar Alfadeela.

Abdelrhman, A. (2009). The Provisions of Temples. Riyadh. Ishbileya.

Abdu, A. B. G. (1392h/1973). Amaghna. Beirut. Dar Alkitab Alarabi.

Ahmed, A. B. T. (1403h). The legitimated Policy in the rehabilitation of Muslims both people and president.

Ahmed, B. T. (1998). Igtidha Alsirat Almustageem Limukhalaft Asshab Aljaheem. Dr. Nasser Alagal, Riyadh. Dar Ishbilya.

Hassan, A. (1998). The Free non-Muslim under Muslims Ruler. Beirut. Dar Algarb Alislami.

Ismael, B. K. (1998). The Interpretation of the Great Quran. Beirut. The House of Scientific Books.

Mohammed, A. (1407h). The encyclopedic of Quran Provisions. Riyadh.

Mohammed, A. L. A. (2005). The Ignominy of a Free non-Muslim under Muslim's rule. Evaluated by: AbdAllahAltriqi, Riyadh. The House of Muslim.

Mohammed, B. U. (1427h). Alsharah Lmumte Ala Zad Almustgne. Riyadh. Dar Bin Aljawzee.

Mohammed, B. Z. (1995). The international Diplomacy in Islam. Egypt. Dar Alfikr Alarabi.

Mohammed, R. (1950). Abu Baker Alsideeg the First Caliphate Succession. Beirut. Dar Ihya Alfiker Alarabi.

Mungiz, A. (2006). Neighborhood with non-Muslims in the Islamic countries. Makah- Islamic Country Associations.

Ragib, A. (2010). The Treatment Art of Prophecy with non-Muslims. Cairo. Dar Algalam.

Saad, Z. A. (2020). The Requirement of the Saudi University Students Immunity Against Extremism, Vision and Immunity form Islamic Educational Perspectives. Majmaah. Journal of Science and Humanities and Management. MajmahUnversity. 
Salih, A. (1421h). An introduction to Psychology. Riyadh. Alrushd Libarary.

Salih, A. (2008). The Rights of non-Muslims in Islamic Countries. Riyadh: The Agency of Pressings. Ministry of Islamic Affairs.

Samlim, A. (2003). The Rules of Treatment with non-Muslim. Egypt. Dar Alwafa.

Saud, A. (1406h). The Contentment with non-Muslims in Muslims' countries. MA Dissertation. Qasim, AL imam Mohammed Bin Saud.

Shams, A. B. A. (2002). The provision of Free non-Muslim Under Muslims' rule.

The juristic Encyclopedia. (2006). Kuwait. Dar Alsalasil.

Will, D. (1988). The Story of Civilization. Translated Version by Badran, Beirut. Dar Aljeel.

\section{Copyrights}

Copyright for this article is retained by the author(s), with first publication rights granted to the journal.

This is an open-access article distributed under the terms and conditions of the Creative Commons Attribution license (http://creativecommons.org/licenses/by/4.0/). 